\title{
PERSEPSI PENGENDARA SEPEDA MOTOR DI KOTA MAKASSAR TERHADAP KEBIJAKAN LARANGAN PENGGUNAAN HANDPHONE SAAT BERKENDARA
}

\section{Perception of Motorcycle Riders in Makassar City Against the Policy of Mobile Phones Use Prohibition When Driving}

\author{
Muhammad Isran Ramli \\ Departemen Teknik Sipil \\ Universitas Hasanuddin \\ Jl. Poros Malino Km. 6 \\ Gowa, Sulawesi Selatan \\ isranramli@unhas.ac.id
}

\author{
Muralia Hustim \\ Departemen Teknik Lingkungan \\ Universitas Hasanuddin \\ Jl. Poros Malino Km. 6 \\ Gowa, Sulawesi Selatan \\ muraliahustim@ft.unhas.ac.id
}

\author{
Mubassirang Pasra \\ Departemen Teknik Sipil \\ Universitas Hasanuddin \\ Jl. Poros Malino Km. 6 \\ Gowa, Sulawesi Selatan \\ mubassirangpasra@unhas.ac.id
}

\begin{abstract}
This study aims to investigate the characteristics of motorcyclists in the city of Makassar and analyze its preference for the policy of prohibiting the use of mobile phones when driving. Data collection was carried out on an arterial road segment in Makassar City using an interview survey method based on questionnaire instruments. The descriptive statistical data analysis approach was conducted to see the significance of the characteristics of motorbike riders against their preferences related to the policy of prohibiting the use of mobile phones when driving. The results of the analysis show that age and education characteristics are two variables that significantly influence motorbike riders' preferences regarding the policy of prohibiting the use of mobile phones when driving. This result is an important information and basis in formulating approach efforts that can be done in terms of strategies for implementing the policy of prohibiting the use of mobile phones when driving in order to improve traffic safety in Indonesia.
\end{abstract}

Keywords: motorcycle riders, mobile phone use, traffic safety.

\begin{abstract}
Abstrak
Studi ini bertujuan menginvestigasi karakteristik pengendara sepeda motor di Kota Makassar dan menganalisis preferensinya terhadap kebijakan larangan penggunaan handphone saat berkendara. Pengumpulan data dilakukan di suatu ruas jalan arteri di di Kota Makassar dengan menggunakan metode survei wawancara berbasis instrument kuesioner. Pendekatan analisis data statistika deskriptif dilakukan untuk melihat signifikansi karakteristik pengendara sepeda motor terhadap preferensinya terkait dengan kebijakan larangan penggunaan handphone saat berkendara. Hasil-hasil analisis memperlihatkan bahwa karakteristik umur dan pendidikan merupakan dua variabel yang secara signifikan mempengaruhi preferensi pengendara sepeda motor terkait kebijakan larangan penggunaan handphone saat berkendara. Hasil ini menjadi informasi dan dasar yang penting dalam perumusan upaya-upaya pendekatan yang dapat dilakukan dalam hal strategi implementasi kebijakan larangan penggunaan handphone saat berkendara dalam rangka meningkatkan keselamatan berlalu lintas di Indonesia.
\end{abstract}

Kata kunci: pengendara sepeda motor, penggunaan handphone, keselamatan berlalu lintas.

\section{PENDAHULUAN}

Dewasa ini, di era desrupsi atau di era revolusi 4.0, penggunaan perangkat teknologi informasi dan komunikasi telah menjadi kebutuhan keseharian masyarakat. Penggunaan telpon genggam atau handphone bagi masyarakat di era sekarang merupakan suatu 
keniscayaan, ketika dimensi waktu dan ruang penggunaannya menjadi tak terbatas. Fenomena ini secara langsung dan secara tidak langsung telah membawa dampak turunan terhadap kelangsungan hidup manusia. Salah satu fokus yang dapat digambarkan adalah telah terjadi peningkatan kecelakaan lalu lintas secara signifkan yang disebabkan oleh penggunaan handphone pada saat berkendaraan oleh pengemudi kendaraan bermotor roda dua dan atau roda empat atau lebih. Dalam rangka menangani masalah ini, Pemerintah Republik Indonesia, dalam hal ini Kepolisian Republik Indonesia, telah mengeluarkan kebijakan berupa pelarangan penggunaan handphone bagi pengendara kendaraan bermotor, termasuk di dalamnya pengendara kendaraan bermotor roda dua atau sepeda motor. Dalam konteks ini, kebijakan tersebut tentunya telah memberikan keterbatasan penggunaan handphone bagi pengguna kendaraan, yang secara umum telah membatasi kebebasan masyarakat dalam penggunaan sarana komunikasi, yang sesungguhnya tidak dapat dibatasi secara privasi.

Perilaku penggunaan handphone ketika berkendara meningkatkan resiko kecelakaan kendaraan motor. Dalam konteks ini, pada banyak negera di dunia telah mengeluarkan kebijakan larangan penggunaan handphone saat berkendara (Backer-Grondahl \& Sagberg, 2011; Roads, 2011; Rozario, Lewis, \& White, 2010). Kebijakan hukum pelarangan ini dikaitkan dengan isu keselamatan lalu lintas yang dihubungkan dengan faktor kognitif dan distrak fisik terhadap perilaku telah diinvestigasi oleh beberapa peneliti sebelumnya (White, Eiser, \& Harris, 2004; Zhou, Rau, Zhang, \& Zhuang, 2012). Dalam rangka memberikan solusi terhadap permasalahan ini, di Australia telah menerapkan "deterrencebased approach" terhadap penggunaan handphone saat berkendara (Walsh, White, Hyde, \& Watson, 2008, p. 1893). Kebijakan ini merupakan kombinasi penegakan hukum dan kampanye pendidikan atau penyadaran (CARRS-Q, 2011) yang bersifat pendidikan. Namun demikian, sanksi hukum hanya mempunyai dampak yang kurang signifikan terhadap perilaku pengendara dalam menggunakan handphone saat berkendara (Nelson, Atchley, \& Little, 2009).

Dalam konteks perilaku pengemudi dan lalu lintas kendaraan bermotor di Indonesia, pertumbuhan kendaraan bermotor baik kendaraan bermotor roda dua maupun kendaraan roda empat dalam satu decade terakhir meningkat secara tajam (Asri dkk, 2012). Kondisi ini membawa kepada perilaku lalu lintas di jaringan jalan perkotaan menjadi lalu lintas yang heterogen (Hustim dkk., 2015). Karateristik dan perilaku lalu lintas heterogen ini telah dan masih memberikan dampak lalu lintas yang signifikan berupa tingginya kejadian kecelakaan lalu lintas di jalan-jalan perkotaan (Halim, dkk., 2017), dan waktu tempuh perjalanan kendaraan bermotor yang meningkat (Sahrullah, dkk 2017). Dari sisi lingkungan, kondisi ini juga menimbulkan dampak polusi udara (Arafah, dkk., 2013, Aly, dkk, 2016) dan kebisingan (Lakawa dkk., 2016; Hustim dkk., 2015). Fokus pada isu kecelakaan dan keselatan lalu lintas, kondisi-kondisi tersebut diperparah dengan perilaku penggunaan handphone pada saat berkendara oleh pengemudi.

Dalam rangka mengurangi dampak turunan terhadap kecelakaan lalu lintas akan perilaku ini, kebijakan pelarangan penggunaan handphone saat berkendara juga telah diterapkan di Indonesia sebagaimana pada sebagaian besar negara di dunia. Untuk melihat sejauhmana efektifitas instrument regulasi ini, sebagai langkah awal diperlukan upaya investigasi terhadap persepsi pengendara kendaraan bermotor khususnya untuk pengendara sepeda motor terhadap kebijakan larangan penggunaan handphone saat berkendara. 
Penelitian ini bertujuan mendeskripsikan dan menganalisis persepsi pengendara sepeda motor terhadap kebijakan larangan penggunaan handphone saat berkendaraan di Kota Makassar. Sebagai studi kasus dipilih Kota Makassar, yang merepresentasikan suatu masyarakat perkotaan yang lalu lintasnya di jalan perkotaan bersifat heterogen.

\section{METODE STUDI}

\section{Variabel Penelitian}

Dalam rangka mendeskripsikan dan menganalisis persepsi pengendara sepeda motor terhadap kebijakan larangan penggunaan handphone saat berkendara, beberapa variabel utama digunakan pada penelitian ini. Variabel-variabel tersebut meliputi karakteristik individu pengendara sepeda motor, yang meliputi usia, pendidikan, pekerjaan dan penghasilan, serta variabel preferensi pengendara sepeda motor terhadap kebijakan larangan penggunaan handphone saat berkendara. Atribut-atribut setiap variabel yang dipertimbangkan pada studi ini disajikan pada Tabel 1.

Tabel 1. Variabel penelitian dan atributnya

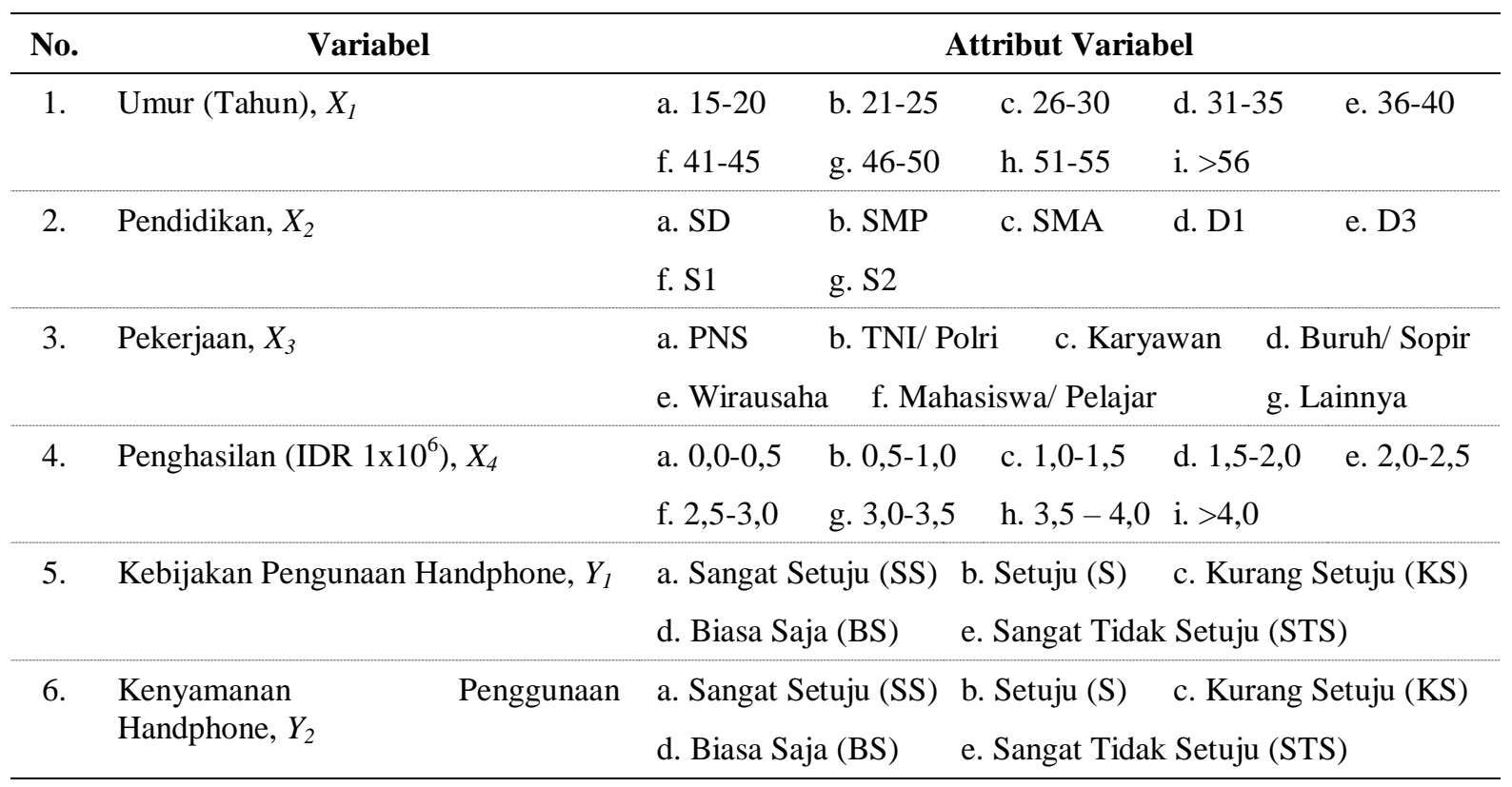

\section{Lokasi Penelitian}

Lokasi survei penelitian ini adalah ruas jalan arteri primer di Kota Makassar, yaitu ruas Jl. A.P. Pettarani. Jalan ini merupakan jalan terbesar dan terpanjang di Kota Makassar, dengan jumlah pengendara sepeda motor sangat besar dan dominan. Secara visual, lokasi penelitian disajikan pada Gambar 1.

\section{Pengumpulan Data}

Pengumpulan data menggunakan instrumen kuesioner, yang memuat sejumlah pertanyaan kepada responden pengendara sepeda motor. Semua pertanyaan terkait dengan variabelvariabel dan atribut variabel yang terdapat pada Tabel 1. 
Metode pengumpulan data yang digunakan pada studi ini adalah metode wawancara langsung oleh surveyor kepada responden pengendara sepeda motor. Wawancara dilakukan dengan menggunakan instrumen kuesioner yang telah didesain.

Untuk memudahkan pelaksanaan survei wawancara terhadap pengguna kendaraan sepeda motor dan dengan mempertimbangkan untuk tidak mengganggu kelancaran arus lalu lintas pada ruas jalan lokasi studi (Jl. AP. Pettarani), survei wawancara dilakukan di StasiunStasiun Pengisian BBM Umum (SPBU) yang terdapat di sepanjang Jl. AP. Pettarani. Dalam hal ini, terdapat 3 lokasi SPBU yang digunakan sebagai tempat pelaksanaan survei wawancara.

Kegiatan wawancara terhadap pengendara sepeda motor dilakukan ketika pengendara sepeda motor menunggu giliran melakukan pengisian bahan bakar. Survei dilakukan pada periode puncak pagi pada tanggal 30 Oktober 2018. Di setiap SPBU dilakukan survei wawancara terhadap sejumlah 320 responden yang dipilih secara acak ketika masuk mengisi BBM di SPBU. Dengan demikian, terdapat total sampel sebanyak 960 responden.

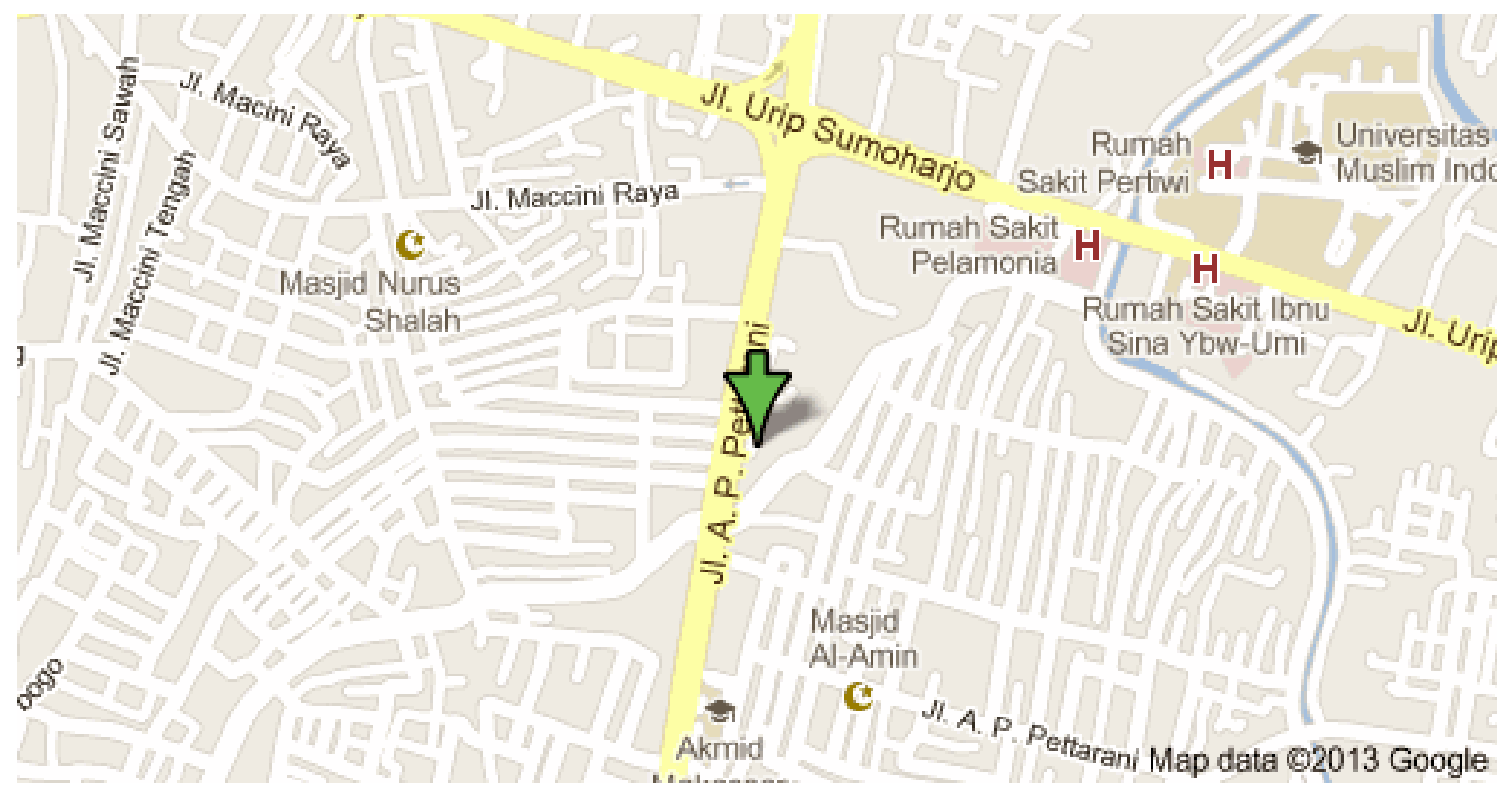

Gambar 1. Lokasi penelitian

\section{Metode Analisis}

Analisis data survei dilakukan dalam 2 tahapan. Tahap pertama adalah analisis dengan pendekatan statistika deskriptif terhadap data karakteristik pengendara sepeda motor. Tahap kedua adalah analisis deskriptif terhadap keterhubungan antar karakteristik pengendara sepeda motor dengan persepsi pengendaraa sepeda motor akan kebijakan larangan penggunaan handphone saat berkendara.

\section{HASIL DAN PEMBAHASAN}

\section{Karakteristik Sebaran Data Pengguna Sepeda Motor}

Karakteristik sebaran data pengguna sepeda motor untuk setiap atribut variabel disajikan pada Tabel 2 dan Gambar 2. Tabel 2 dan Gambar 2 memperlihatkan bahwa atribut 
dominan untuk variabel umur pengguna sepeda motor adalah kategori (15-20) tahun dan kategori (21-25) tahun, yang memiliki proporsi $20,4 \%$ dan $22,7 \%$, secara berurut. Untuk karakteristik pendidikan, terlihat bahwa pengguna sepeda yang dominan berpendidikan SMA dan Sarjana S1. Dari segi karakteristik pekerjaan, atribut pengguna sepeda motor yang dominan adalah berprofesi sebagai Mahasiswa/Pelajar, disusul oleh Karyawan dan PNS. Berdasarkan karakteristik penghasilan terlihat bahwa pengendara sepeda motor yang dominan memiliki penghasilan $(0,5-1,0)$ juta rupiah dan $(2,0-2,5)$ juta rupiah.

Tabel 2. Karakteristik sebaran data untuk setiap atribut variabel

\begin{tabular}{|c|c|c|c|c|}
\hline No. & Variabel & \multicolumn{3}{|c|}{ Frekuensi (\%) } \\
\hline \multirow[t]{3}{*}{1.} & Umur (Tahun), $X_{1}$ & a. $15-20(20,4)$ & d. $31-35(13,2)$ & g. $46-50(5,5)$ \\
\hline & & b. $21-25(22,7)$ & e. $36-40(8,3)$ & h. $>50(4,0)$ \\
\hline & & c. $26-30(19,7)$ & f. $41-45(6,2)$ & \\
\hline \multirow[t]{3}{*}{2.} & Pendidikan, $X_{2}$ & a. $\operatorname{SD}(1,7)$ & d. D1 $(1,5)$ & g. S2 $(1,9)$ \\
\hline & & b. SMP $(6,4)$ & e. D3 $(5,7)$ & \\
\hline & & c. SMA $(49,9)$ & f. S1 $(32,9)$ & \\
\hline \multirow[t]{4}{*}{3.} & Pekerjaan, $X_{3}$ & a. PNS $(14,0)$ & \multicolumn{2}{|c|}{ e. Wirausaha $(10,8)$} \\
\hline & & b. TNI/Polri $(1,3)$ & \multicolumn{2}{|c|}{ f. Mahasiswa/Pelajar $(34,2)$} \\
\hline & & c. Karyawan $(26,8)$ & \multicolumn{2}{|c|}{ g. Lainnya $(9,1)$} \\
\hline & & \multicolumn{3}{|l|}{ d. Buruh/Sopir $(3,8)$} \\
\hline \multirow[t]{3}{*}{4.} & Penghasilan (IDR $1 \times 10^{6}$ ), $X_{4}$ & a. $0,0-0,5(9,3)$ & d. $1,5-2,0(6,6)$ & g. $3,0-3,5(16,8)$ \\
\hline & & b. $0,5-1,0(26,5)$ & e. $2,0-2,5(21,2)$ & h. $3,5-4,0(4,5)$ \\
\hline & & c. $1,0-1,5(10,0)$ & f. $2,5-3,0(1,3)$ & i. $>4,0(3,8)$ \\
\hline \multirow[t]{2}{*}{5.} & Kebijakan Pengunaan Handphone, $Y_{1}$ & a. SS (43) & c. $\mathrm{KS}(8)$ & e. STS (0) \\
\hline & & b. S (49) & d. BS (0) & \\
\hline
\end{tabular}

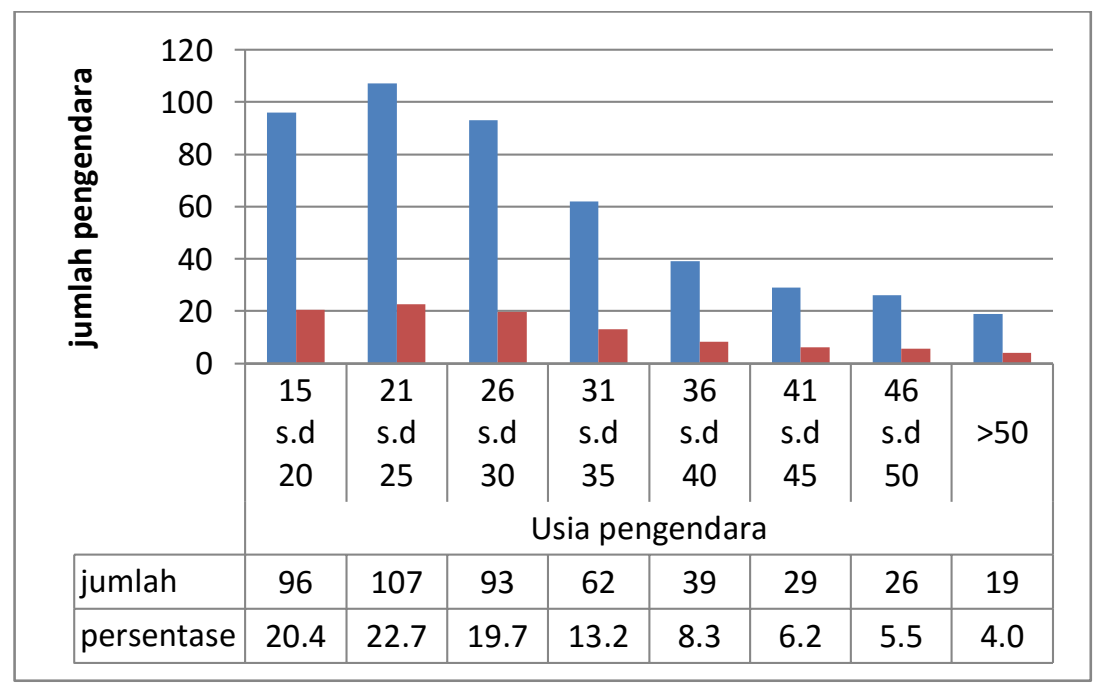

Gambar 2a. Karakteristik pengguna sepeda motor berdasarkan usia 


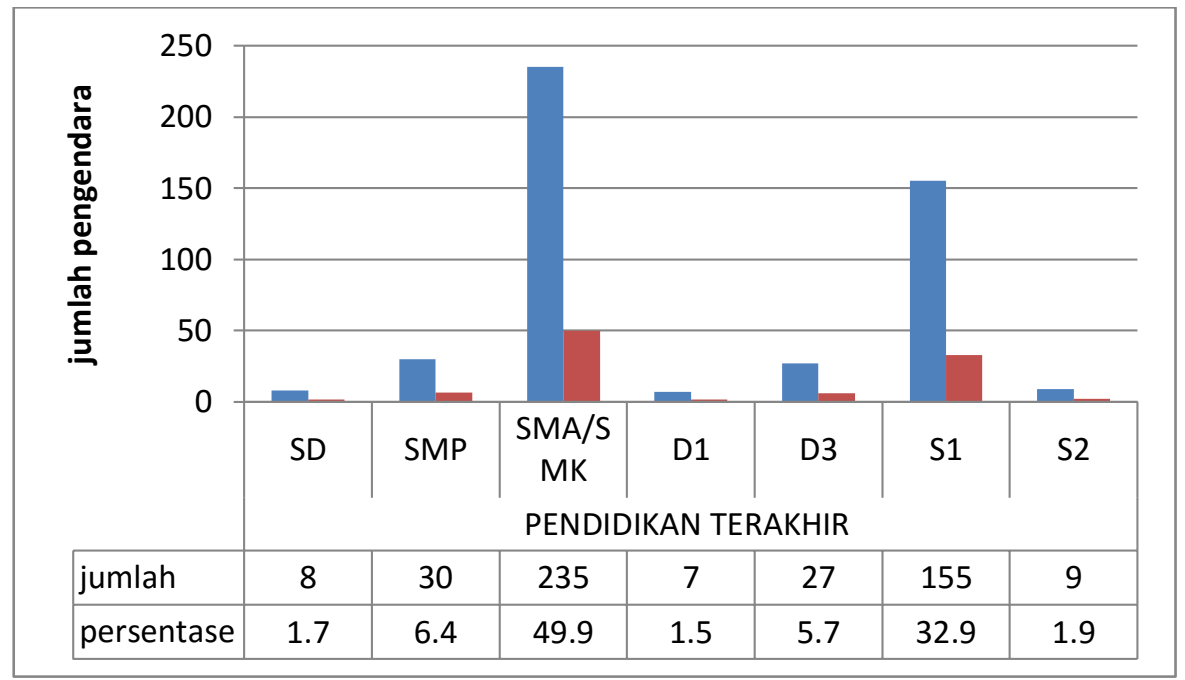

Gambar 2b. Karakteristik pengguna sepeda motor berdasarkan pendidikan terakhir

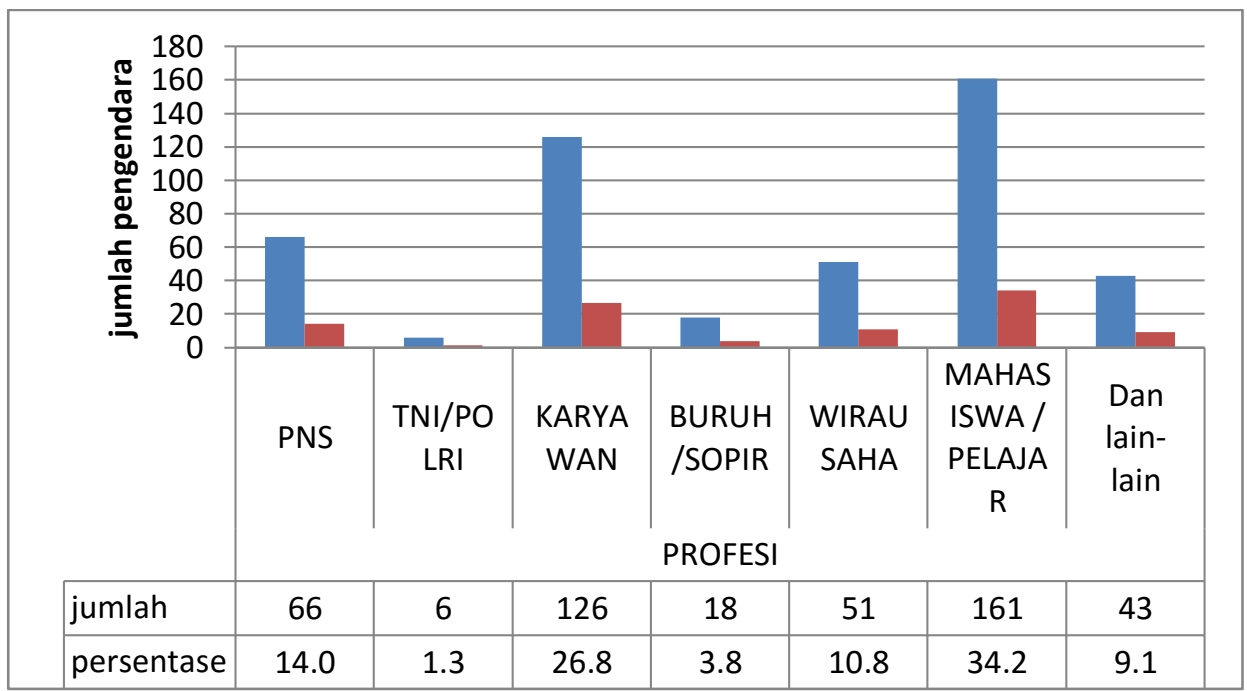

Gambar 2c. Karakteristik pengguna sepeda motor berdasarkan profesi/pekerjaan

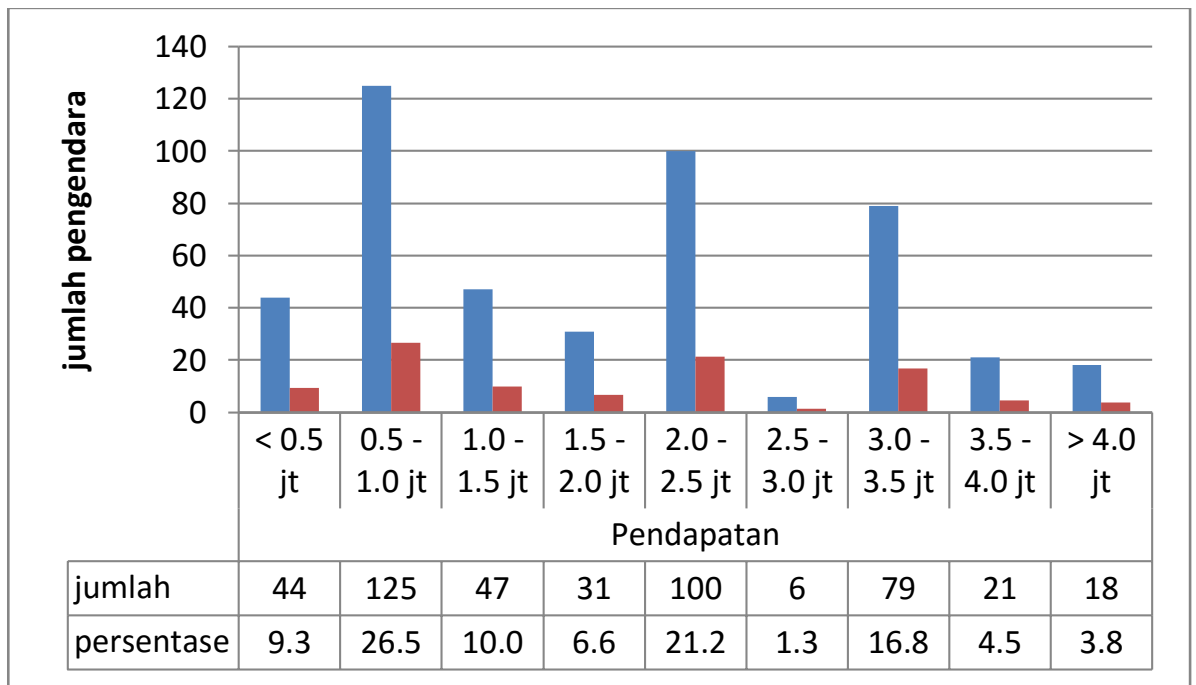

Gambar 2d. Karakteristik pengguna sepeda motor berdasarkan penghasilan 
Tabel 2 dan Gambar 2 juga memperlihatkan komposisi preferensi pengendara sepeda motor terhadap kebijakan larangan penggunaan handphone saat berkendara, baik untuk kebijakan maupun untuk kenyamanan penggunaannya. Preferensi pengendara sepeda motor terhadap kebijakan larangan penggunaan handphone saat berkendara didominasi oleh preferensi setuju dan sangat setuju secara berimbang. Namun demikian masih terdapat porsi kecil yang menyatakan kurang setuju. Hal ini sejalan pula dengan preferensi pengguna sepeda motor terhadap kenyamanan penggunaan handphone saat berkendara.

Untuk menganalisis lebih jauh secara deskriptif terhadap kedua jenis preferensi pengendara sepeda akan kebijakan larangan penggunaan handphone, pada bagian berikut dilakukan analisis deskriptif pola hubungan antara persepsi pengendara sepeda motor terhadap kebijakan larangan penggunaan handphone.

\section{Persepsi Pengendara Sepeda Motor terhadap Kebijakan Larangan Penggunaan HP}

Secara visual analisis deskriptif pola hubungan antara persepsi pengendara sepeda motor terhadap kebijakan larangan penggunaan handphone dapat dilihat pada Gambar 3. Hasilhasil analisis pola hubungan secara deskriptif yag dilakukan dapat memberikan dasar yang kuat untuk dilakukan analisis atau model pemetaan persepsi pengguna sepeda motor terhadap kebijakan larangan penggunaan handphone saat berkendara.

Pada Gambar 3a diperlihatkan respons pengendara sepeda motor pada berbagai kategori usia terhadap kebijakan larangan penggunaan handphone saat berkendara. Mayoritas pengguna sepeda motor setuju dan sangat setuju dengan kebijakan tersebut. Namun demikian, terdapat pula pengendaraa sepeda motor yang menyatakan ketidaksetujuannya. Proporsi terbesar yang tidak setuju adalah pengendaraa sepeda motor berusia remaja dan pemuda, dengan usia $(15-25)$ tahun.

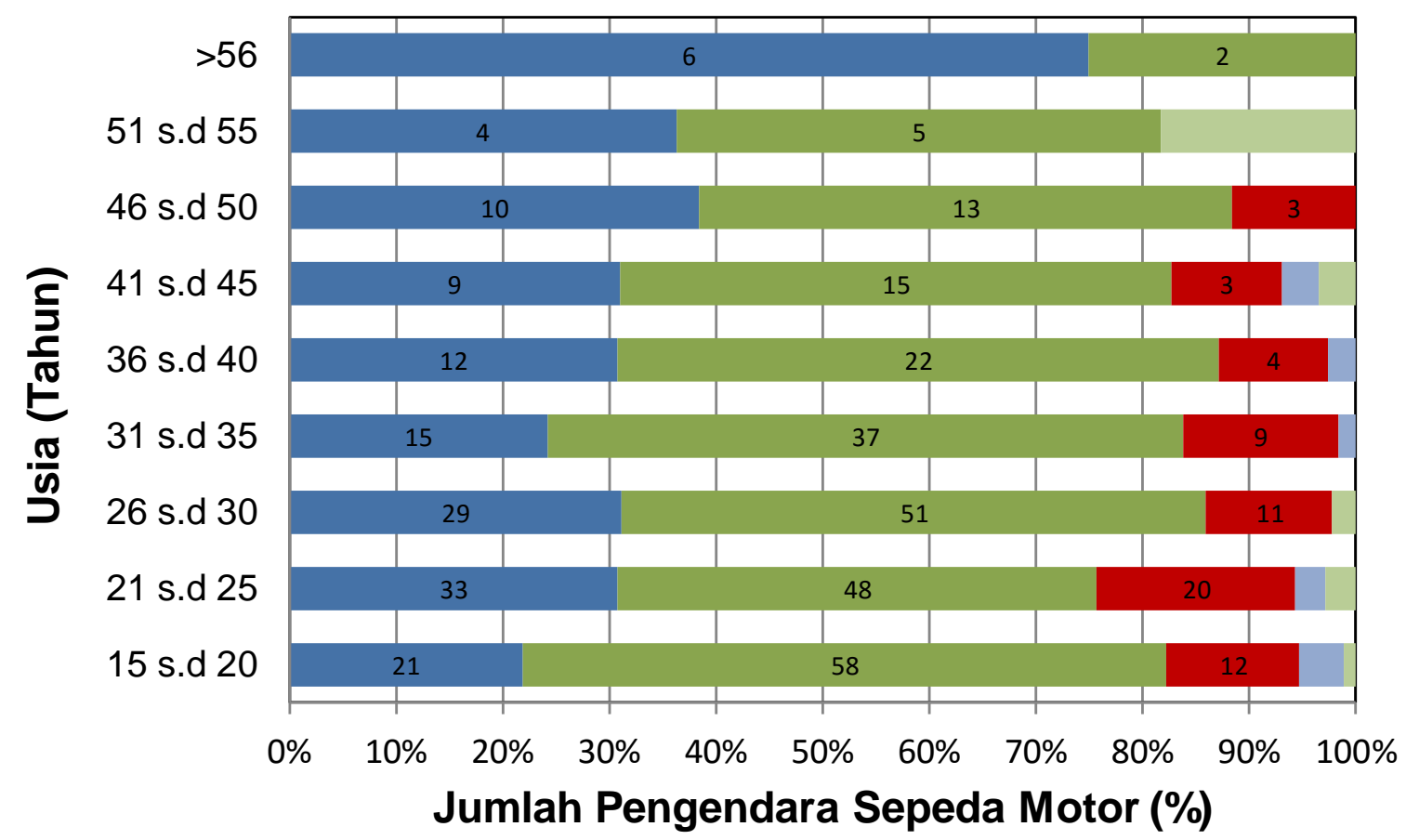

$\square$ Sangat Setuju $\square$ Setuju $\quad$ Kurang Setuju Biasa Saja $\square$ Sangat Tidak Setuju

a. Usia 


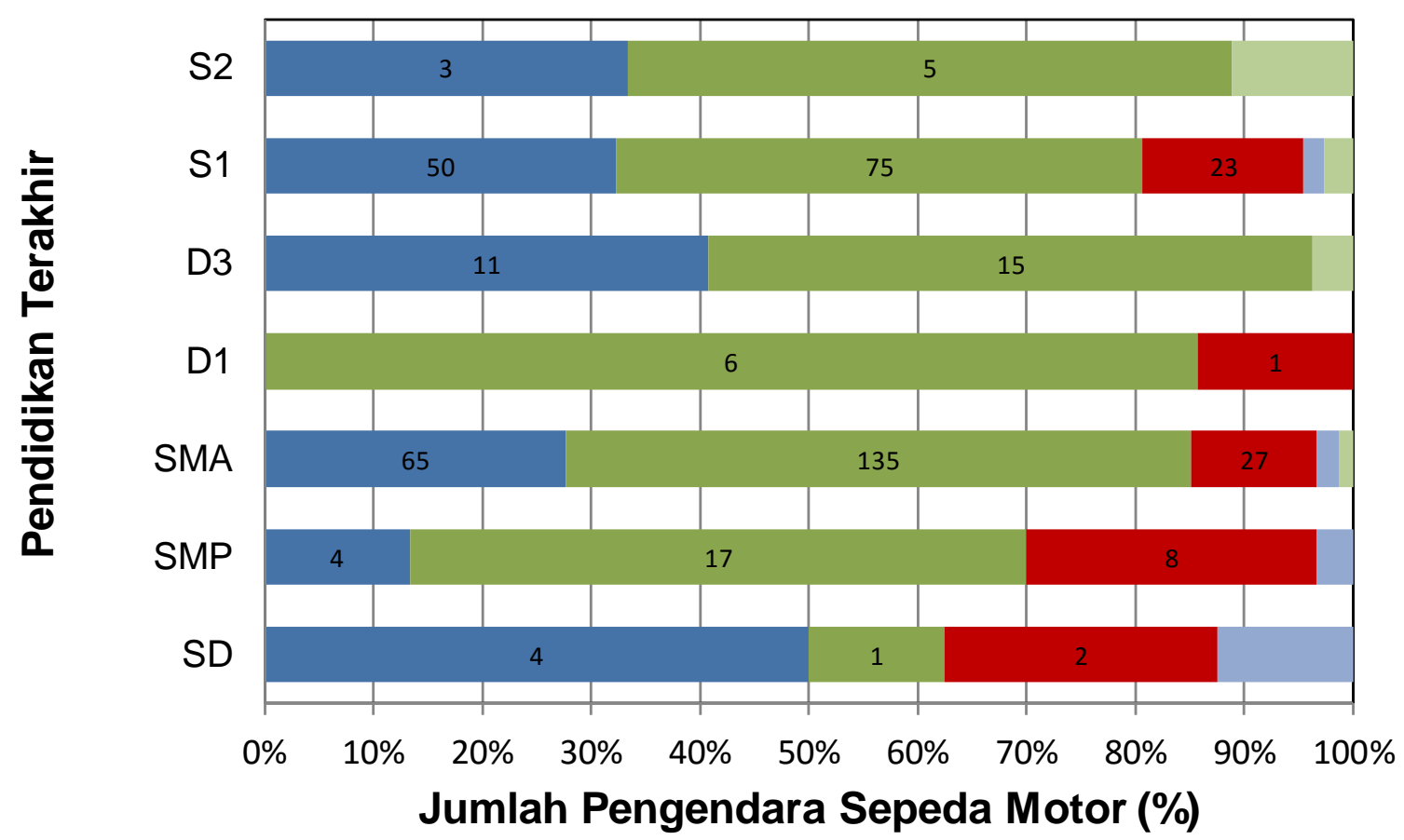

$\square$ Sangat Setuju $\quad$ Setuju $\quad$ Kurang Setuju $\quad$ Biasa Saja $\square$ Sangat Tidak Setuju

b. Pendidikan Terakhir

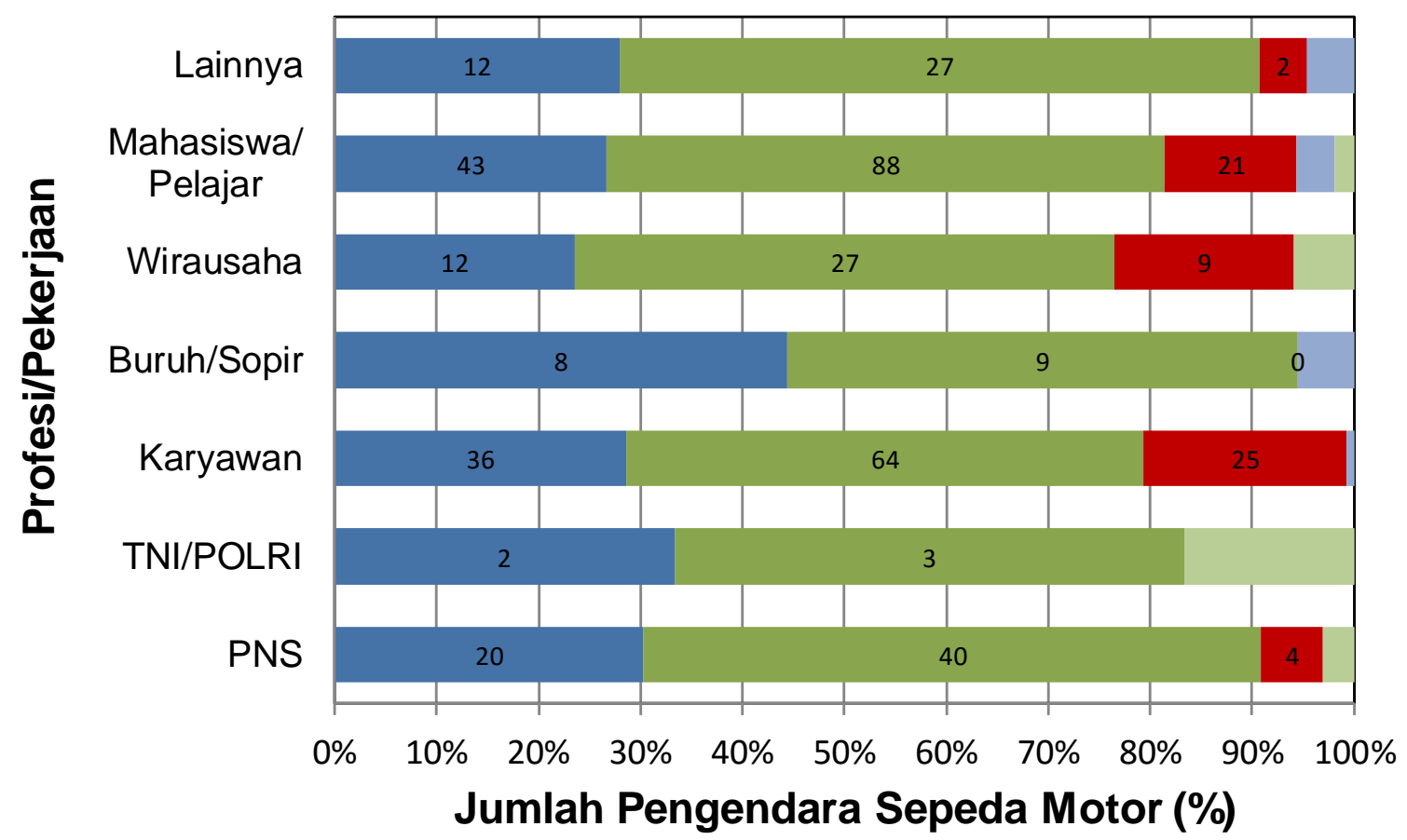

-Sangat Setuju $\quad$ Setuju $\quad$ Kurang Setuju $\backsim$ Biasa Saja $\backsim$ Sangat Tidak Setuju

c. Profesi/Pekerjaan 


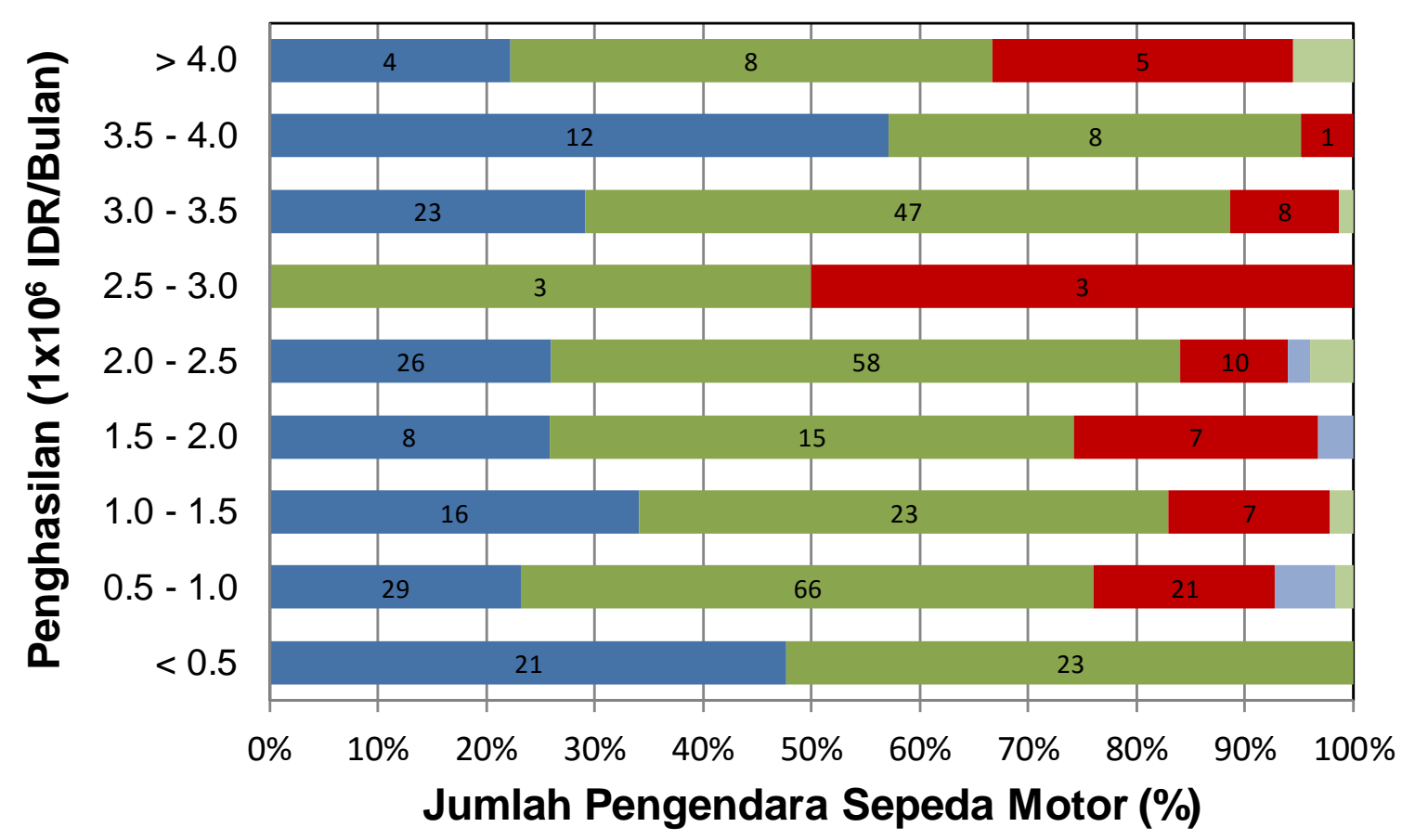

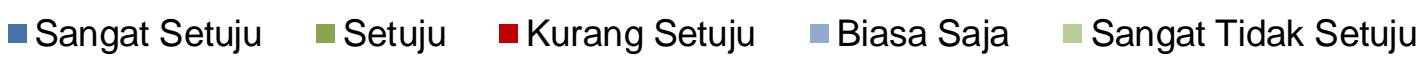

\section{d. Penghasilan}

Gambar 3. Persepsi vs Karakteristik pengendara SM terhadap kebijakan penggunaan HP

Gambar 3b memperlihatkan bahwa sebagian besar pengendara sepeda motor, dengan semua kategori Pendidikan, menyatakan kesetujuannya terhadap kebijakan larangan penggunaan handphone saat berkendara. Terdapat sebagian kecil, antara $5 \%$ hingga 25\%, pengendara sepeda motor yang menyatakan ketidaksetujuannya terhadap kebijakan larangan penggunaan handphone saat berkendara. Terlihat pada stud ini bahwa pengendara sepeda motor dengan tingkat pendidikan terendah (SD dan SMP) memiliki persepsi ketidaksetujuan yang paling besar.

Gambar 3c menyajikan persepsi pengendara sepeda motor dengan berbagai kategori pekerjaaan. Mayoritas pengendara sepeda motor menyatakan kesetujuannya terhadap kebijakan larangan penggunaan handphone saat berkendara. Hanya sedikit pengendara sepeda motor yang menyatakan ketidasetujuannya terhadap kebijakan larangan penggunaan handphone saat berkendara, yaitu antara $(5-20) \%$ dengan berbagai kategori pekerjaan.

Gambar 3d memperlihatkan persepsi pengendara sepeda motor mulai dari kategori berpenghasilan rendah hingga kategori berpenghasilan tinggi, yang setuju terhadap kebijakan larangan penggunaan handphone saat berkendara. Pengendara yang kurang setuju didominasi oleh mereka yang berpenghasilan $(2,5-3,0)$ juta rupiah per bulan.

\section{KESIMPULAN}

Studi ini telah menginvestigasi dan mengeksplorasi preferensi pengendara sepeda motor di Kota Makassar terhadap kebijakan larangan penggunaan handphone saat berkendara. Dengan menggunakan pendekatan metode wawancara berbasis instrumen kuesioner, 
berbagai hasil data karakteristik penggunaa sepeda motor dideskripsikan dan preferensi pengendara sepeda motor terhadap kebijakan tersebut dianalisis secara statistika deskriptif.

Umur dan pendidikan terakhir pengendara, yang menjadi responden, merupakan dua faktor utama yang memberikan pengaruh terhadap preferensi pengendara sepeda motor terhadap kebijakan larangan penggunaan handphone saat berkendara. Kedua variabel ini sangat berkaitan erat dalam hal stratafikasi pengguna sepeda motor. Hasil-hasil analisis perlu ditindaklanjuti dalam bentuk analisis secara hubungan kuantitatif dengan menggunakan pendekatan model ordered logit pada tahapan analisis atau studi lanjutan.

Hasil studi ini sangat bermanfaat dalam memberikan informasi terkait potensi strategi yang perlu dilakukan oleh pemangku kepentingan dalam rangka implementasi aturan tertib berlalu lintas untuk pengendara sepeda motor, terkait dengan kebijakan larangan penggunaan handphone saat berkendara. Hal ini dimaksudkan untuk meningkatkan keselamatan berlalu lintas di Kota Makassar pada khususnya, dan di kota-kota besar di Indonesia pada umumnya.

\section{UCAPAN TERIMA KASIH}

Ucapan terima kasih disampaikan kepada Korlantas POLRI yang telah mendanai kegiatan penelitian ini melalui lembaga Traffic Accident Research Center (TARC). Ucapan terima kasih juga disampaikan kepada pihak Dirlantas Polda Sulsel beserta jajarannya yang telah membantu dalam pengambilan data dalam penelitian ini.

\section{DAFTAR PUSTAKA}

Asri, A., Ramli., M. I., Samang, L. 2012. A Study on Motorcycle Ownership of Residential Households in Makassar. Proceeding of The $15^{\text {th }}$ FSTPT International Symposium, STTD Bekasi, November 23-24, 2012.

Asri, A., Ramli, M. I., Samang, L. 2011. Motorcyclist Acceptability on Road Safety Policy: Motorcycle Exclusive Lane in Makassar. Proceeding of the 15th FSTPT International Symposium, Pekanbaru, November 11-13, 2011.

Backer-Grondahl \& Sagberg, 2011, Driving and telephoning: Relative accident risk when using hand-held and hands-free mobile phones. Safety Science, 49, 324-330.

CARRS-Q, 2011, State of the road: Mobile phones and driving fact sheet. <http://www.carrsq.qut.edu.au/publications/corporate/mobile_phones_and_driving_f s.pdf.

H Halim, SA Adisasmita, MI Ramli, SH Aly, 2017, The Pattern of Severity of Traffic Accidents on Traffic Conditions Heterogeneous, International Journal of Civil Engineering and Technology (IJCIET) 8 (4), 1720-1729.

I Lakawa, L Samang, M Selintung, M Hustim, 2016, Factors Affecting Traffic Noise Based On Road Environment Aspects, International Journal of Engineering and Science Applications 2 (2), 117-124.

Koppelman, F.S., and Bhat, C. 2006. A Self Instructing Course in Mode Choice Modeling: Multinomial and Nested Logit Model. U.S. Department of Transportation Federal Transit Administration.

M Hustim, MI Ramli, SH Aly, 2015, An Investigation on the Sound Power Level of Vehicles in Makassar City, Proceedings of the Eastern Asia Society for Transportation Studies 10. 
Nelson, Atchley, \& Little, 2009, The effects of perception of risk and importance of answering and initiating a cellular phone call while driving. Accident Analysis and Prevention, 41(3), 438-444.

Roads, 2011, Mobile phone use.<http://www.rta.nsw.gov.au/roadsafety/driverdistractions/ index.html>.

Rozario, Lewis, \& White, 2010, An examination of the factors that influence drivers' willingness to use hand-held mobile phones. Transportation Research: Part F, 13(6), 365-376.

Sahrullah, MI Ramli, N Ali, R Rahim, 2017, A Travel Time Estimation Model of Private Cars in Urban Arterial Roads Based on Heterogeneous Traffic, International Journal of Civil Engineering and Technology 8 (7), 676-685.

SH Aly, MI Ramli, 2016, A development of MARNI 12.2 model: A calculation tool of vehicular emission for heterogeneous traffic conditions, Journal of Engineering and Applied Sciences 11 (1), 43-50.

Wedagama, D.M.P., and Dissanayake, D. 2010. Analysing Motorcycle Injuries on Arterial Roads in Bali Using Multinomial Logit Model. Journal of the Eastern Asia Society for Transportation Studies, Vol.8, pp. 1892-1904.

Walsh, White, Hyde, \& Watson, 2008, Dialling and driving: Factors influencing intentions to use a mobile phone while driving. Accident Analysis and Prevention, 40(6), $1893-$ 1900.

White, Eiser, \& Harris, 2004, Risk perceptions of mobile phone use while driving. Risk Analysis, 24(2), 323-334.

Zhou, R., Rau, P.-L. P., Zhang, W., \& Zhuang, D., 2012, Mobile phone use while driving: Predicting drivers' answering intentions and compensatory decisions. Safety Science, 50(1), 138-149. 